\title{
Early-Onset Cerebral Amyloid Angiopathy and Alzheimer Disease Related to an APP Locus Triplication
}

Lou Grangeon, MD, Kévin Cassinari, MD, Stéphane Rousseau, BSc, Bernard Croisile, MD, Maïté Formaglio, MD, Olivier Moreaud, MD, Jean Boutonnat, MD, Nathalie Le Meur, PharmD, Manuele Miné, PharmD, PhD,

Thibault Coste, MD, Eva Pipiras, MD, PhD, Elisabeth Tournier-Lasserve, MD, PhD, Anne Rovelet-Lecrux, PhD, Dominique Campion, MD, PhD, David Wallon, MD, PhD, and Gael Nicolas, MD, PhD

Neurol Genet 2021;7:e609. doi:10.1212/NXG.0000000000000609

\section{Abstract}

\section{Background and Objective}

To report a triplication of the amyloid- $\beta$ precursor protein $(A P P)$ locus along with relative messenger RNA (mRNA) expression in a family with autosomal dominant early-onset cerebral amyloid angiopathy (CAA) and Alzheimer disease (AD).

\section{Methods}

Four copies of the APP gene were identified by quantitative multiplex PCR of short fluorescent fragments, fluorescent in situ hybridization (FISH), and array comparative genomic hybridization. APP mRNA levels were assessed using reverse-transcription-digital droplet PCR in the proband's whole blood and compared with 10 controls and 9 APP duplication carriers.

\section{Results}

Beginning at age 39 years, the proband developed severe episodic memory deficits with a CSF biomarker profile typical of $\mathrm{AD}$ and multiple lobar microbleeds in the posterior regions on brain MRI. His father had seizures and recurrent cerebral hemorrhage since the age of 37 years. His cerebral biopsy showed abundant perivascular amyloid deposits, leading to a diagnosis of CAA. In the proband, we identified 4 copies of a 506-kb region located on chromosome $21 \mathrm{q} 21.3$ and encompassing the whole APP gene without any other gene. FISH suggested that the genotype of the proband was 3 copies/ 1 copy corresponding to an APP locus triplication, which was consistent with the presence of $2 A P P$ copies in the healthy mother and with the paternal medical history. Analysis of the APP mRNA level showed a 2 -fold increase in the proband and a 1.8 fold increase in APP duplication carriers compared with controls.

\section{Discussion}

Increased copy number of $A P P$ is sufficient to cause $\mathrm{AD}$ and CAA, with likely earlier onset in case of triplication compared with duplication.
Correspondence

Dr. Nicolas

gaelnicolas@hotmail.com

\section{RELATED ARTICLE}

\section{Editorial}

The Dose Makes the

Poison

Page e610

From the Department of Neurology and CNR-MAJ (L.G., D.W.), Normandie University, UNIROUEN, Inserm U1245, CHU Rouen, CIC-CRB1404, F 76000; Department of Genetics and CNR-MAJ (K.C., S.R., N.L.M., A.R.-L., D.C., G.N.), Normandie University, UNIROUEN, Inserm U1245 and CHU Rouen, F 76000; Department of Neurology (B.C., M.F.), Lyon University Hospital; Department of Neurology (O.M.), Grenoble University Hospital; Department of Histology (J.B.), Grenoble University Hospital; AP-HP (M.M., T.C., E.T.-L.), Groupe Hospitalier Saint-Louis Lariboisière-Fernand-Widal, Service de Génétique Moléculaire Neurovasculaire, INSERM UMR 1141, NeuroDiderot,Université de Paris; Department of Histology Embryology and Cytogenetics (E.P.), Jean Verdier Hospital; Paris 13 University (E.P.), Sorbonne Paris Cité, UFR SMBH Bobigny; and PROTECT (E.P.), INSERM, Paris Diderot University, Bondy, France. 


\section{Glossary}

aCGH = array comparative genomic hybridization; $\mathbf{A D}=$ Alzheimer disease APP $=$ amyloid $-\beta$ precursor protein; $\mathbf{C A A}=$ cerebral amyloid angiopathy; EOAD = early-onset Alzheimer disease; MMSE = Mini Mental State Examination; $\mathbf{m R N A}=$ messenger RNA; QMPSF = quantitative multiplex PCR of short fluorescent fragments.

Amyloid- $\beta$ precursor protein $(A P P)$ is the main gene known to be involved in autosomal dominantly inherited cerebral amyloid angiopathy (CAA). After the description of point mutations, APP locus duplications were identified in 2006 as a cause of early-onset CAA and/or early onset Alzheimer disease (EOAD, onset before 65 years). ${ }^{1}$ Such copy number variations encompass at least the APP gene, with or without surrounding genes on chromosome $21,{ }^{2}$ and are associated with $\sim 1.5$-fold increased messenger RNA (mRNA) levels in blood compared with healthy controls, in similar ranges to patients with trisomy 21 . $^{3}$ The size of the duplication and the gene content-beyond the critical APP gene-do not appear to influence phenotypic presentation in cases. ${ }^{1,4-6}$ Patients with trisomy 21 usually show cognitive impairment similar to Alzheimer disease ( $\mathrm{AD})$, although they less frequently exhibit cerebral hematoma, suggesting the presence of protective mechanisms in patients with Down syndrome. ${ }^{7}$ Indeed, a recent histopathologic study showed more severe CAA but less parenchymal amyloid plaque formation in APP duplication than in trisomy 21 patients. ${ }^{7}$ Given this diversity in amyloid distribution according to the underlying genetic background, CAA pathogenesis remains to be understood. We here report an APP locus triplication, along with relative mRNA expression in the proband's blood.

\section{Case Presentation}

A 41-year-old man without medical history was referred to a memory care center for the evaluation of progressive cognitive decline. ${ }^{8}$ From age 39 years, he presented with an aggressive course of episodic memory loss making him unable to maintain his professional activity as well as attention deficit and executive dysfunction. The Mini Mental State Examination (MMSE) scored 18/30 and Frontal Assessment Battery $15 / 18$. There was neither language impairment nor praxis or visuoconstructive dysfunction. The patient did not present any episode suggestive of stroke or seizures. Brain MRI showed multiple lobar microbleeds in the posterior fossa and occipital region and posterior periventricular leukoencephalopathy (Figure 1A) with hippocampal atrophy (bilateral Scheltens scale rating of 2). He underwent lumbar puncture for quantification of CSF $\mathrm{AD}$ biomarkers $\mathrm{A} \beta 42$, tau, and phosphorylated-tau. The $\mathrm{A} \beta_{42}$ level was decreased ( $404 \mathrm{ng} / \mathrm{L}$, $\mathrm{N}>550)$, with increased tau $(491 \mathrm{ng} / \mathrm{L}, \mathrm{N}<400)$ and phospho-tau protein levels $(95 \mathrm{ng} / \mathrm{L}, \mathrm{N}<60)$. The $\mathrm{A} \beta_{40}$ level was $8,546 \mathrm{ng} / \mathrm{L}(4,540<\mathrm{N}<8,480)$. Overall, he fulfilled the diagnostic criteria of probable $\mathrm{AD}$ with evidence of the $\mathrm{AD}$ pathophysiologic process, ${ }^{8}$ in association with probable CAA following the modified Boston criteria, except the age criterion.

His father had had recurrent migraine with visual aura and presented at age 37 years with transient loss of consciousness (Figure 1B). Focal epilepsy was diagnosed after recurrent episodes of contact loss and electroencephalography showing slow bilateral temporal waves and then treated by carbamazepine. Subsequent cerebral MRI showed hyperintensities in

Figure 1 Partial Pedigree, Cerebral MRI of the Proband, and Histopathologic Examination of the Cerebral Biopsy Performed in His Father

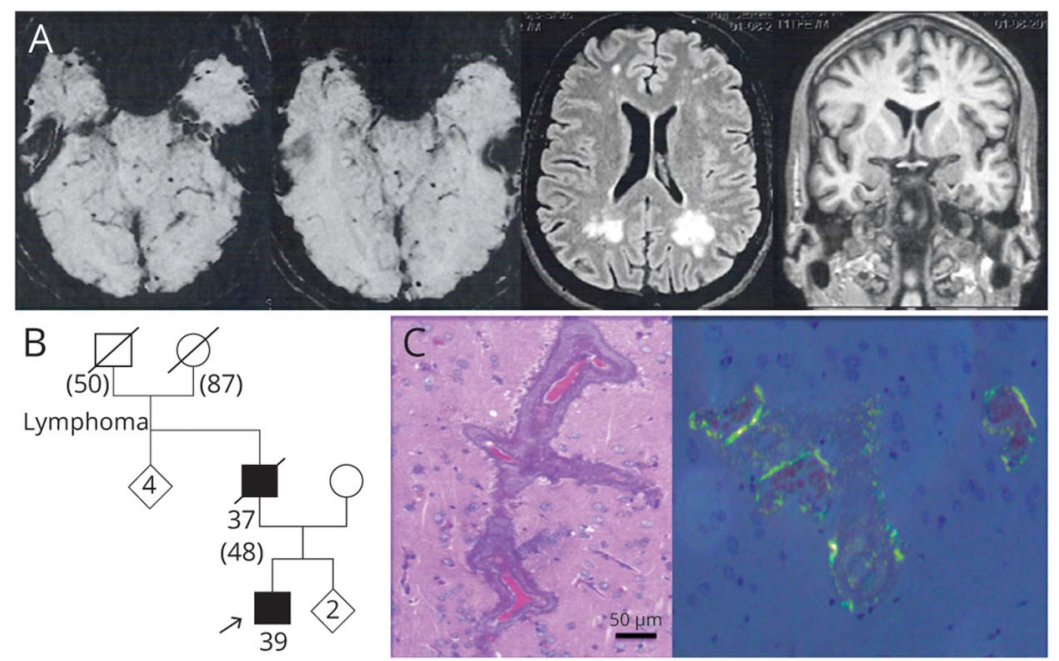

(A) $\mathrm{T}^{*}$ weighted sequence showing multiple lobar microbleeds (first and second images); FLAIR-weighted sequence showing posterior leukoaraiosis (third image) and coronal view of T1-weighted sequence showing moderate bilateral hippocampal atrophy (fourth image). (B) Age at death (in parentheses) and age at onset are indicated. The proband is identified by an arrow. (C) Histopathologic examination of the cerebral biopsy of the proband's father. Bouin-fixed paraffin sections of the cerebral biopsy were stained with hematoxylin-eosin (left part) and Congo red (right part). Sections stained with Congo red were examined under crossed polarized light for analyzing vascular amyloid and revealed apple-green birefringence of amyloid material in blood vessel walls. 
A

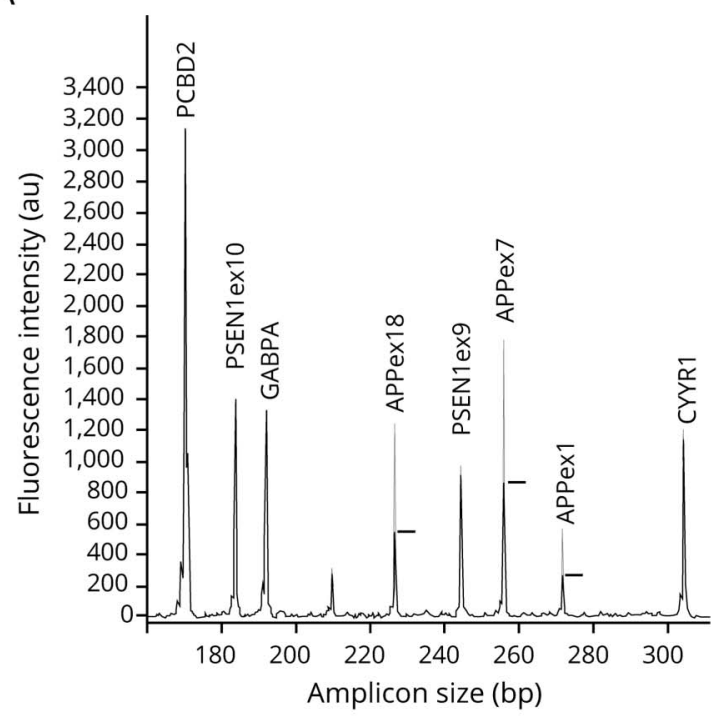

B

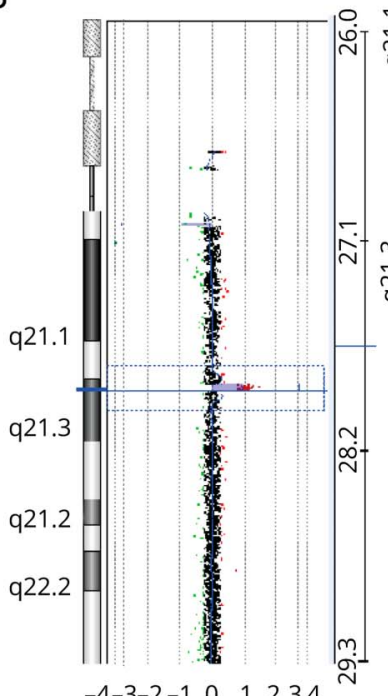

$-4-3-2-1 \quad 0 \quad 1234$

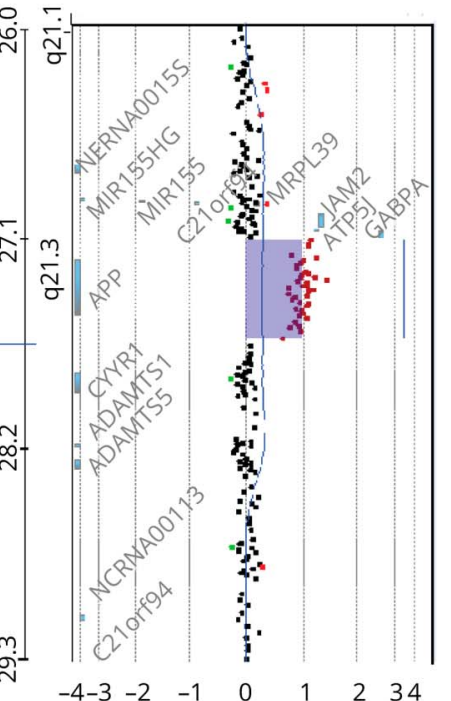

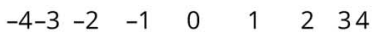

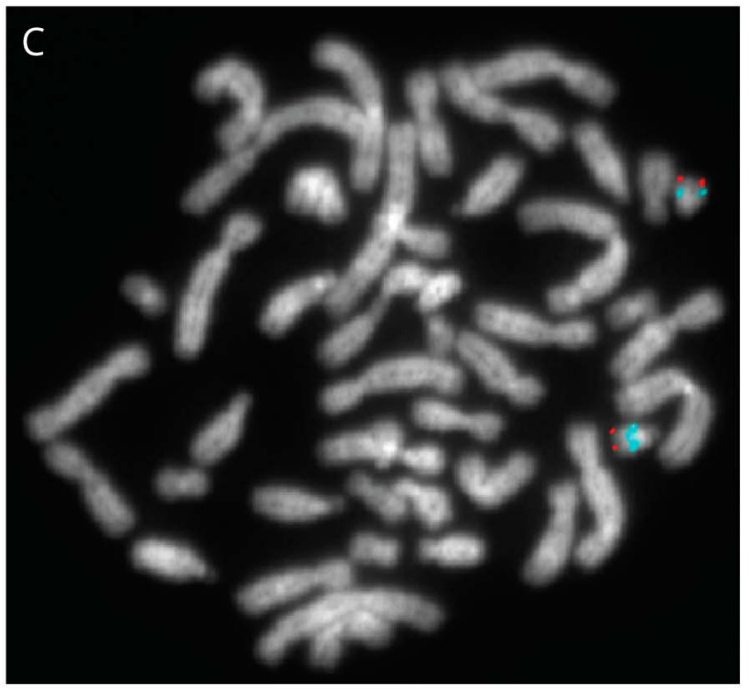

D

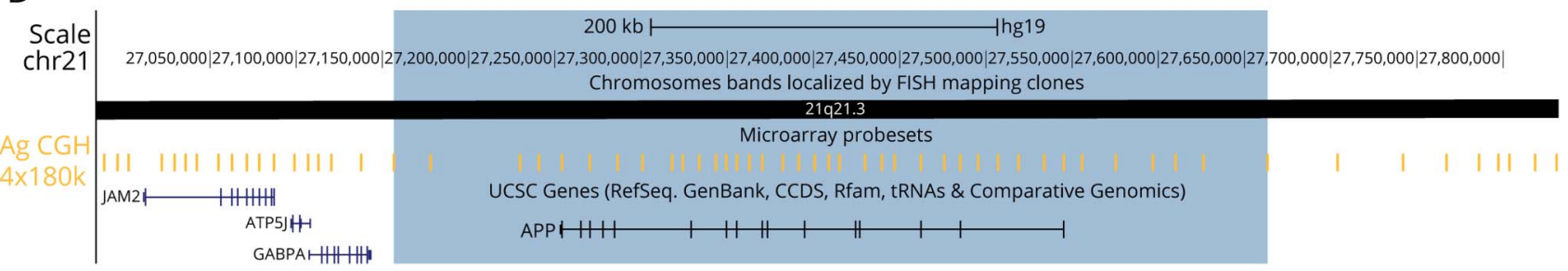

(A) Detection by QMPSF of an APP triplication. The electropherogram of the proband (in light gray) was superimposed on that of a normal individual (in black) by adjusting to the same level the peaks obtained from the control amplicon PCBD2 located on chromosome 5 . The vertical axis shows fluorescence in arbitrary units, and the horizontal axis indicates the size of the amplicon in base pairs. Horizontal bars indicate triplication of the amplicons, detected by a 2 fold heightening of the corresponding peaks. This QMPSF also covers 2 genes located at 21q21, GABPA and CYYR1 that are not duplicated. (B) Refinement of triplication breakpoints by array CGH. Representation on the Agilent Genomic Workbench 7.0 software of the 21q21.3 triplication (log ratio: 0.97) on chr21: $38,156,233,-27,662,338 ;$;g 19. (C) FISH analysis of peripheral blood lymphocytes of the proband. Red: control probe located on chromosome 21 long arm subtelomeric region (VIJyRM2029, Vysis; Abbott, Chicago, IL); Blue: APP locus specific probe (RP11-410J1; Empire Genomics, Buffalo, NY) located on 21q21.3. (D) Gene content of the triplicated region: Visualization in the UCSC genome browser of the 21q21.3 triplication chr21:27,156,233-27,662,338; hg19 (blue highlight). Yellow bars represent array CGH probes. Yellow bars at both extremes of the blue zone represent the last triplicated probes. The reference assembly used is GRCh37/hg19. Other panels represent, from top to bottom: Agilent 180K probes, cytogenetic band, UCSC genes (only RefSeq sequence). APP $=$ amyloid $-\beta$ precursor protein; FISH = fluorescent in situ hybridization.

centrum semiovale on T2-weighted sequences. CSF was acellular and showed a moderately high protein level $(0.61 \mathrm{~g} /$ $\mathrm{L})$, but $\mathrm{AD}$ biomarkers were not available at this time.
Progressive behavioral disorders and severe cognitive impairment occurred 4 years later and worsened over time with an MMSE of 24/30. Neuropsychological testing showed 
Figure 3 Expression Analysis Using RT-ddPCR

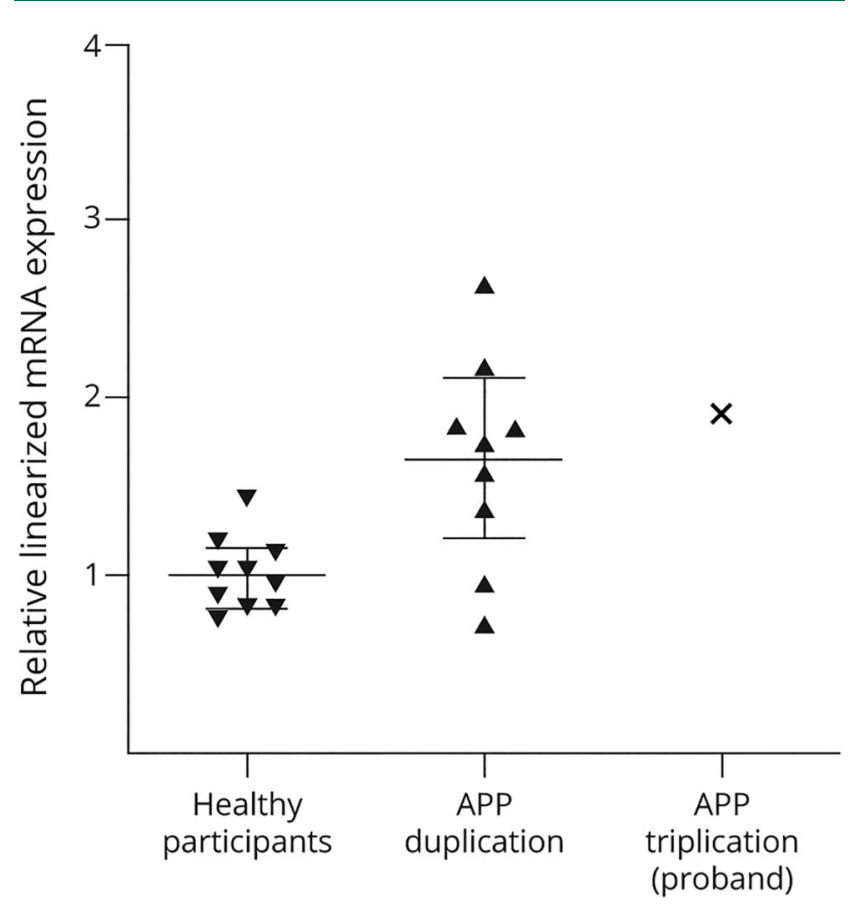

RT-ddPCR with a target amplicon in the APP gene and a reference amplicon in the $D L G 4$ housekeeping gene for healthy controls $(\mathrm{N}=10)$, patients carrying an $A P P$ duplication $(\mathrm{N}=9)$, and our patient carrying an APP triplication $(\mathrm{N}=1)$. Each point represents the average of 3 measures obtained for an individual (except for the proband where the point represents the average of 5 measures). Results are presented through an expression ratio APP/DLG4 linearized with the average expression ratio of controls: For each group, the median relative APP mRNA expression is indicated with a wide horizontal line, and 95\% confidence intervals are shown with short horizontal lines. APP = amyloid- $\beta$ precursor protein; $m R N A$ = messenger RNA; RT-ddPCR = reverse-transcription-digital droplet PCR.

episodic memory loss associated with praxis and visuoconstructive moderate dysfunction. He thus fulfilled the diagnostic criteria of probable $\mathrm{AD}^{8}$ and probable CAA. Tc99m-HMPAO cerebral single photon emission computerized tomography was considered normal. At age 44 years, his condition was extremely severe with repeated loss of consciousness episodes and major upper cerebral dysfunction. Cerebral MRI showed acute bilateral temporal hematomas and posterior leukoencephalopathy. Cerebral angiography did not display any sign of cerebral vasculitis. Cerebral biopsy revealed abundant perivascular amyloid deposits enabling the final diagnosis of probable CAA with supporting pathological evidence (Figure $1 \mathrm{C}$ ). He died at age 48 years after a second hemorrhagic event with left temporal hematoma. There was no history of dementia or stroke in his family, although a censoring effect was noticed: the paternal grandfather of the proband indeed died at age 50 years from lymphoma (Figure 1B).

\section{Genetic Assessment}

We obtained informed written consent for genetic analyses by the patient and by the father's legal representative. This study was approved by the Institutional Review Board of Rouen University Hospital (CERDE \#2019-55 notification).
Quantitative multiplex PCR of short fluorescent fragment (QMPSF) analyses performed from DNA isolated from fresh whole blood revealed 4 copies of the APP gene in the proband (Figure 2A). His $A P O E$ genotype was 33, and Sanger sequencing did not detect any point mutation in exons 16-17 of $A P P$. The 68-year-old unaffected mother carried 2 copies of $A P P$, suggesting a $3+1$ genotype in the proband, but no DNA sample was available from his father. Fluorescent in situ hybridization using APP locus specific probes (RP11-410J1; Empire Genomics, Williamsville, NY) on cultured lymphocytes metaphase cells showed an asymmetric positive hybridization signal on chromosome 21 long arm without other signal hybridization anywhere else (Figure $2 \mathrm{C}$ ), further suggesting a $3+$ 1 genotype and hence autosomal dominant transmission of a triplication.

We further mapped the triplication using array comparative genomic hybridization (aCGH, Agilent SurePrint 4 × 180k; Agilent Technologies, Santa Clara, CA). The 506-kb 21q21.3 triplication (chr21:27,156,233-27,662,338;hg19) was restricted to the whole $A P P$ gene without any flanking gene coding sequence (Figure 2, B and D).

Finally, mRNA APP levels were assessed using reversetranscription-digital droplet PCR in the proband whole blood comparatively to 10 normal controls (including the proband's mother) and 9 patients carrying $A P P$ duplications (see eMethods, links.lww.com/NXG/A465). The patient showed a 2-fold increase of relative $A P P$ mRNA levels compared with controls (Figure 3 and eFigure 1, links.lww.com/NXG/ A470). Patients with APP duplication showed a median of 1.8 fold increase compared with controls, but no comparison could be directly made with our proband, considering this single $A P P$ triplication case.

\section{Discussion}

To our knowledge, this is the first report of an APP locus triplication, causing a two-fold upregulation of $A P P$ mRNA levels, in a family presenting with autosomal dominant EOAD with severe CAA. Although duplications of a given gene are now a classical cause of several autosomal dominant disorders, there are few examples of mendelian diseases caused by a gene triplication. In the field of neurodegenerative diseases, SNCA triplications on chromosome 4 have been reported in patients with Parkinson or Lewy body disease along with duplications in other patients. ${ }^{9}$ As for the APP gene, alpha-synucleinencoding SNCA increased gene copies encompassed at least the SNCA gene, with or without surrounding genes (1 to 50), and displayed high diversity in clinical phenotype. ${ }^{10}$ Similarly, since its first description, some diversity of phenotypes associated with $A P P$ duplications has been described, mostly related to the predominance of $\mathrm{AD}$ or CAA-related symptoms at presentation. ${ }^{6}$ In this report, triplication was associated with diverse presentation, including severe cognitive disorder in the proband and recurrent $\mathrm{ICH}$ and seizures in his father. 
The higher copy number seemed to be associated with earlier symptomatic phase in our report (37 and 39 years of age at onset) compared with APP duplications carriers showing ages at onset ranging from 39 to 65 years. ${ }^{1,4-6}$ However, we can expect some degree of diversity in ages of onset in other APP triplication families.

In a recent French series of EOAD, APP duplication carriers were more likely to present with seizures, ${ }^{11}$ possibly explained by $A \beta$ overproduction related to increased $A P P$ expression. Early seizures may be a shared clinical feature with $A P P$ triplication as observed in the father of the proband.

Different mechanisms can be involved in autosomal dominant $\mathrm{CAA}$ and $\mathrm{AD}$ pathogenesis. In contrast with $A P P$ point mutations, which can result in increased beta cleavage of APP, change in $A \beta 42 / 38$ ratio, or in $A \beta$ aggregation propensity, ${ }^{12}$ $A P P$ duplications lead to APP overproduction, with severe $A \beta$ deposits in the brain parenchyma and within vessels walls. ${ }^{1,3}$ Here, cerebral biopsy of the proband's father confirmed severe amyloid perivascular deposits consecutive to APP overproduction. Indeed, we found a 2-fold upregulation of $A P P$ mRNA levels in blood. Unfortunately, no comparison could be made with $A P P$ duplication carriers given the availability of RNA in the proband only so that we cannot be sure that triplications result in significantly increased mRNA levels than in duplication.

Here, we showed by aCGH that the triplication encompassed the APP gene only. To our knowledge, there is a single case report of an $A P P$ duplication encompassing the $A P P$ gene solely, highlighting that increased APP expression is sufficient to cause EOAD and CAA. ${ }^{2}$ However, the resolution of the techniques did not allow us to assess whether the breakpoints were the same in our case and in this 290-750 kb duplication. ${ }^{2}$ The mechanisms underlying genomic instability of the APP region remain elusive, and further reports are needed to refine shared or novel breakpoints.

Overall, our report provides further evidence that increased $A P P$ expression is sufficient to lead to $A \beta$ aggregation and subsequent $\mathrm{EOAD}$ and $\mathrm{CAA}$. Although ages at clinical onset were among the earliest ones in our $A P P$ triplication carriers compared with duplication carriers, further cases would be required to conclude.

\section{Study Funding}

No targeted funding reported.

\section{Disclosure}

The authors report no disclosures relevant to the manuscript. Go to Neurology.org/NG for full disclosures.

\section{Publication History}

Received by Neurology: Genetics April 1, 2021. Accepted in final form June 8, 2021.

\section{Appendix Authors}

\begin{tabular}{|c|c|c|}
\hline Name & Location & Contribution \\
\hline $\begin{array}{l}\text { Lou } \\
\text { Grangeon, } \\
\text { MD }\end{array}$ & $\begin{array}{l}\text { Department of Neurology and } \\
\text { CNR-MAJ, UNIROUEN, Inserm } \\
\text { U1245, CHU Rouen, CIC- } \\
\text { CRB1404, F-76000 Rouen, } \\
\text { France }\end{array}$ & $\begin{array}{l}\text { Collection, interpretation } \\
\text { of data, and drafting and } \\
\text { manuscript revision }\end{array}$ \\
\hline $\begin{array}{l}\text { Kévin } \\
\text { Cassinari, } \\
\text { MD }\end{array}$ & $\begin{array}{l}\text { Department of Genetics and } \\
\text { CNR-MAJ, Normandie University, } \\
\text { UNIROUEN, Inserm U1245 and } \\
\text { CHU Rouen, F-76000 Rouen, } \\
\text { France }\end{array}$ & $\begin{array}{l}\text { Collection, statistical } \\
\text { analysis, and } \\
\text { interpretation of data and } \\
\text { drafting of the manuscript }\end{array}$ \\
\hline $\begin{array}{l}\text { Stéphane } \\
\text { Rousseau, } \\
\text { BSc }\end{array}$ & $\begin{array}{l}\text { Department of Genetics } \\
\text { and CNR-MAJ, Normandie } \\
\text { University, UNIROUEN, } \\
\text { Inserm U1245 and CHU } \\
\text { Rouen, F-76000 Rouen, } \\
\text { France }\end{array}$ & $\begin{array}{l}\text { Collection, analysis, and } \\
\text { interpretation of data }\end{array}$ \\
\hline $\begin{array}{l}\text { Bernard } \\
\text { Croisile, MD }\end{array}$ & $\begin{array}{l}\text { Department of Neurology, } \\
\text { Lyon University Hospital, } \\
\text { France }\end{array}$ & $\begin{array}{l}\text { Collection and } \\
\text { interpretation of data }\end{array}$ \\
\hline $\begin{array}{l}\text { Maïté } \\
\text { Formaglio, } \\
\text { MD }\end{array}$ & $\begin{array}{l}\text { Department of Neurology, } \\
\text { Lyon University Hospital, } \\
\text { France }\end{array}$ & $\begin{array}{l}\text { Collection and } \\
\text { interpretation of data }\end{array}$ \\
\hline $\begin{array}{l}\text { Olivier } \\
\text { Moreaud, } \\
\text { MD }\end{array}$ & $\begin{array}{l}\text { Department of Neurology, } \\
\text { Grenoble University Hospital, } \\
\text { France }\end{array}$ & $\begin{array}{l}\text { Collection and } \\
\text { interpretation of data }\end{array}$ \\
\hline $\begin{array}{l}\text { Jean } \\
\text { Boutonnat, } \\
\text { MD }\end{array}$ & $\begin{array}{l}\text { Department of Neurology, } \\
\text { Grenoble University Hospital, } \\
\text { France }\end{array}$ & $\begin{array}{l}\text { Collection, analysis, and } \\
\text { interpretation of data }\end{array}$ \\
\hline $\begin{array}{l}\text { Nathalie Le } \\
\text { Meur, } \\
\text { PharmD }\end{array}$ & $\begin{array}{l}\text { Department of Genetics and } \\
\text { CNR-MAJ, Normandie } \\
\text { University, UNIROUEN, Inserm } \\
\text { U1245 and CHU Rouen, } \\
\text { F-76000 Rouen, France }\end{array}$ & $\begin{array}{l}\text { Collection and } \\
\text { interpretation of data }\end{array}$ \\
\hline
\end{tabular}

\begin{tabular}{lll}
\hline $\begin{array}{l}\text { Manuele } \\
\text { Miné, } \\
\text { PharmD, PhD }\end{array}$ & $\begin{array}{l}\text { AP-HP, Groupe Hospitalier } \\
\text { Saint-Louis Lariboisière- } \\
\text { Fernand-Widal, Service de } \\
\text { Génétique Moléculaire } \\
\text { Neurovasculaire, } \\
\text { INSERM UMR 1141, }\end{array}$ & $\begin{array}{l}\text { Collection and } \\
\text { interpretation of data }\end{array}$ \\
& $\begin{array}{l}\text { NeuroDiderot,Université } \\
\text { de Paris, France }\end{array}$ & \\
& & \\
\hline Thibault & AP-HP, Groupe Hospitalier & Collection and \\
Coste, MD & Saint-Louis Lariboisière- & interpretation of data \\
& $\begin{array}{l}\text { Fernand-Widal, Service de } \\
\text { Génétique Moléculaire }\end{array}$ & \\
& Neurovasculaire, & \\
& INSERM UMR 1141, \\
& NeuroDiderot,Université \\
de Paris, France &
\end{tabular}

\begin{tabular}{lll}
\hline Eva Pipiras, & Department of Histology & Collection and \\
MD, PhD & Embryology and Cytogenetics, & interpretation of data \\
& Jean Verdier Hospital; Paris 13 & \\
& University, Sorbonne Paris & \\
& Cité, UFR SMBH Bobigny; & \\
& PROTECT, INSERM, Paris & \\
& Diderot University, Bondy, & \\
& France & \\
\hline Elisabeth & AP-HP, Groupe Hospitalier & Interpretation of data and \\
Tournier & Saint-Louis Lariboisière- & drafting and manuscript \\
Lasserve, & Fernand-Widal, Service de & revision \\
MD, PhD & Génétique Moléculaire & \\
& Neurovasculaire, & \\
& INSERM UMR 1141, & \\
& NeuroDiderot,Université & \\
& de Paris, France &
\end{tabular}


Appendix (continued)

\begin{tabular}{|c|c|c|}
\hline Name & Location & Contribution \\
\hline $\begin{array}{l}\text { Anne } \\
\text { Rovelet- } \\
\text { Lecrux, PhD }\end{array}$ & $\begin{array}{l}\text { Department of Genetics } \\
\text { and CNR-MAJ, Normandie } \\
\text { University, UNIROUEN, } \\
\text { Inserm U1245 and CHU } \\
\text { Rouen, F-76000 Rouen, } \\
\text { France }\end{array}$ & $\begin{array}{l}\text { Collection, analysis, and } \\
\text { interpretation of data }\end{array}$ \\
\hline $\begin{array}{l}\text { Dominique } \\
\text { Campion, } \\
\text { MD, PhD }\end{array}$ & $\begin{array}{l}\text { Department of Genetics } \\
\text { and CNR-MAJ, Normandie } \\
\text { University, UNIROUEN, } \\
\text { Inserm U1245 and CHU } \\
\text { Rouen, F-76000 Rouen, } \\
\text { France }\end{array}$ & $\begin{array}{l}\text { Collection, analysis, and } \\
\text { interpretation of data }\end{array}$ \\
\hline $\begin{array}{l}\text { David } \\
\text { Wallon, MD, } \\
\text { PhD }\end{array}$ & $\begin{array}{l}\text { Department of Neurology } \\
\text { and CNR-MAJ, Normandie } \\
\text { University, UNIROUEN, } \\
\text { Inserm U1245, CHU } \\
\text { Rouen, CIC-CRB1404, } \\
\text { F-76000 Rouen, } \\
\text { France }\end{array}$ & $\begin{array}{l}\text { Study concept, } \\
\text { interpretation of data, and } \\
\text { drafting and manuscript } \\
\text { revision }\end{array}$ \\
\hline $\begin{array}{l}\text { Gael Nicolas, } \\
\text { MD, PhD }\end{array}$ & $\begin{array}{l}\text { Department of Genetics } \\
\text { and CNR-MAJ, Normandie } \\
\text { University, UNIROUEN, } \\
\text { Inserm U1245 and CHU } \\
\text { Rouen, F-76000 Rouen, } \\
\text { France }\end{array}$ & $\begin{array}{l}\text { Study concept, } \\
\text { interpretation of data, and } \\
\text { drafting and manuscript } \\
\text { revision }\end{array}$ \\
\hline
\end{tabular}

\section{References}

1. Rovelet-Lecrux A, Hannequin D, Raux G, et al. APP locus duplication causes autosomal dominant early-onset Alzheimer disease with cerebral amyloid angiopathy. Nat Genet. 2006;38(1):24-26.

2. Sleegers K, Brouwers N, Gijselinck I, et al. APP duplication is sufficient to cause early onset Alzheimer's dementia with cerebral amyloid angiopathy. Brain. 2006;129(pt 11):2977-2983.

3. Pottier $\mathrm{C}$, Wallon $\mathrm{D}$, Lecrux AR, et al. Amyloid- $\beta$ protein precursor gene expression in Alzheimer's disease and other conditions. J Alzheimers Dis. 2012;28(3):561-566.

4. Wallon D, Rousseau S, Rovelet-Lecrux A, et al. The French series of autosomal dominant early onset Alzheimer's disease cases: mutation spectrum and cerebrospinal fluid biomarkers. J Alzheimers Dis. 2012;30(4):847-856.

5. Lanoiselee H-M, Nicolas G, Wallon D, et al. APP, PSEN1, and PSEN2 mutations in early-onset Alzheimer disease: a genetic screening study of familial and sporadic cases. PLoS Med. 2017;14(3):e1002270.

6. Guyant-Marechal I, Berger E, Laquerriere A, et al. Intrafamilial diversity of phenotype associated with app duplication. Neurology. 2008;71(23):1925-1926.

7. Mann DMA, Davidson YS, Robinson AC, et al. Patterns and severity of vascular amyloid in Alzheimer's disease associated with duplications and missense mutations in APP gene, Down syndrome and sporadic Alzheimer's disease. Acta Neuropathol (Berl). 2018;136(4):569-587.

8. McKhann GM, Knopman DS, Chertkow H, et al. The diagnosis of dementia due to Alzheimer's disease: Recommendations from the National Institute on Aging-Alzheimer's Association workgroups on diagnostic guidelines for Alzheimer's disease. Alzheimers Dement. 2011;7(3):263-269.

9. Zafar F, Valappil RA, Kim S, et al. Genetic fine-mapping of the Iowan SNCA gene triplication in a patient with Parkinson's disease. NPJ Park Dis. 2018;4:18. Accessed October 2, 2020. nature.com/articles/s41531-018-0054-4.

10. Book A, Guella I, Candido T, et al. A meta-analysis of $\alpha$-synuclein multiplication in familial Parkinsonism. Front Neurol. 2018;9:1021. Accessed October 2, 2020. frontiersin.org/article/10.3389/fneur.2018.01021/full.

11. Zarea A, Charbonnier C, Rovelet-Lecrux A, et al. Seizures in dominantly inherited Alzheimer disease. Neurology. 2016;87(9):912-919.

12. Greenberg SM, Bacskai BJ, Hernandez-Guillamon M, Pruzin J, Sperling R, van Veluw SJ. Cerebral amyloid angiopathy and Alzheimer disease-one peptide, two pathways. Nat Rev Neurol. 2020;16(1):30-42. 


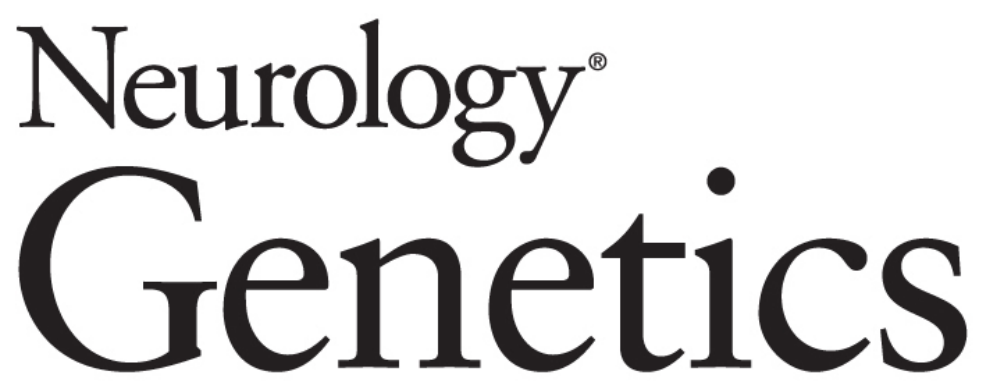

Early-Onset Cerebral Amyloid Angiopathy and Alzheimer Disease Related to an APP Locus Triplication

Lou Grangeon, Kévin Cassinari, Stéphane Rousseau, et al. Neurol Genet 2021;7;

DOI 10.1212/NXG.0000000000000609

This information is current as of September 8, 2021

Neurol Genet is an official journal of the American Academy of Neurology. Published since April 2015, it is an open-access, online-only, continuous publication journal. Copyright Copyright ( 2021 The Author(s). Published by Wolters Kluwer Health, Inc. on behalf of the American Academy of Neurology.. All rights reserved. Online ISSN: 2376-7839.

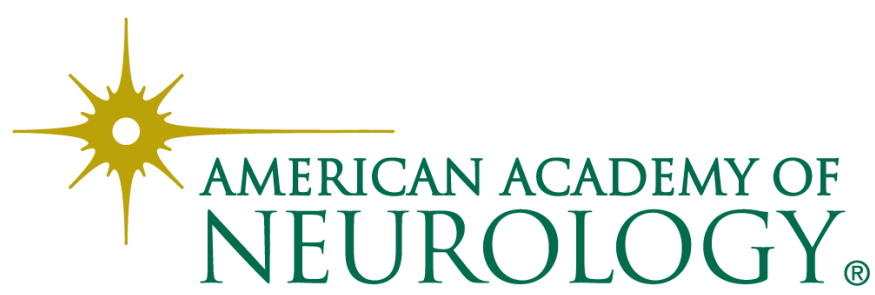




\section{Updated Information \& Services}

References

Citations

Subspecialty Collections

Permissions \& Licensing

Reprints including high resolution figures, can be found at: http://ng.neurology.org/content/7/5/e609.full.html

This article cites 12 articles, 0 of which you can access for free at: http://ng.neurology.org/content/7/5/e609.full.html\#\#ref-list-1

This article has been cited by 2 HighWire-hosted articles: http://ng.neurology.org/content/7/5/e609.full.html\#\#otherarticles

This article, along with others on similar topics, appears in the following collection(s):

Alzheimer's disease

http://ng.neurology.org//cgi/collection/alzheimers_disease Gene expression studies

http://ng.neurology.org//cgi/collection/gene_expression_studies

Intracerebral hemorrhage

http://ng.neurology.org//cgi/collection/intracerebral_hemorrhage

Information about reproducing this article in parts (figures,tables) or in its entirety can be found online at:

http://ng.neurology.org/misc/about.xhtml\#permissions

Information about ordering reprints can be found online:

http://ng.neurology.org/misc/addir.xhtml\#reprintsus

Neurol Genet is an official journal of the American Academy of Neurology. Published since April 2015, it is an open-access, online-only, continuous publication journal. Copyright Copyright $\odot 2021$ The Author(s). Published by Wolters Kluwer Health, Inc. on behalf of the American Academy of Neurology.. All rights reserved. Online ISSN: 2376-7839.

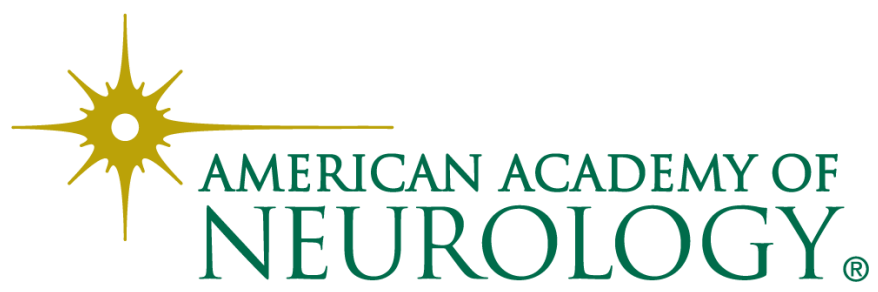

